\title{
Immune checkpoint receptors: homeostatic regulators of immunity
}

\author{
Antonio Riva ${ }^{1,2}$ (D) Shilpa Chokshi ${ }^{1,2}$ (D)
}

Received: 5 February 2018 / Accepted: 23 April 2018/Published online: 8 May 2018

(C) The Author(s) 2018

\begin{abstract}
Alcoholic liver disease (ALD) is an escalating global problem accounting for more than 3 million deaths annually. Bacterial infections are diagnosed in 25-47\% of hospitalized patients with cirrhosis and represent the most important trigger for acute decompensation, multi-organ failure, septic shock and death. Current guidelines recommend intensive antibiotic therapy, but this has led to the emergence of multi-drug resistant bacteria, which are associated with increased morbidity and mortality rates. As such, there is a pressing need to explore new paradigms for anti-infective therapy and host-directed immunomodulatory therapies are a promising approach. Paradoxically, cirrhotic patients are characterised by heightened immune activity and exacerbated inflammatory processes but are unable to contend with bacterial infection, demonstrating that whilst immune effector cells are primed, their antibacterial effector functions are switched-off, reflecting a skewed homeostatic balance between anti-pathogen immunity and host-induced immunopathology. Preservation of this equilibrium physiologically is maintained by multiple immune-regulatory checkpoints and these feedback receptors serve as pivotal regulators of the host immunity. Checkpoint receptor blockade is proving to be effective at rescuing deranged/exhausted immunity in pre-clinical studies for chronic viral infection and sepsis. This approach has also obtained FDA approval for restoring anti-tumor immunity, with improved response rates and good safety profiles. To date, no clinical studies have investigated checkpoint blockade in ALD, highlighting an area for development of host-targeted immunotherapeutic strategies in ALD, for which there are no current specific treatment options. This review aims at framing current knowledge on immune checkpoints and the possibility of their therapeutic utility in ALD-associated immune dysfunctions.
\end{abstract}

Keywords Checkpoint · Immunotherapy $\cdot$ ALD

$\begin{array}{ll}\text { Abbreviations } \\ \text { ARC } & \text { Alcohol-related cirrhosis } \\ \text { APC } & \text { Antigen-presenting cell } \\ \text { CD } & \text { Cluster of differentiation } \\ \text { CTLA-4 } & \text { Cytotoxic T-lymphocyte associated protein } 4 \\ \text { IFN } & \text { Interferon } \\ \text { IL } & \text { Interleukin } \\ \text { LAG-3 } & \text { Lymphocyte-activation gene } 3\end{array}$

This review is based on a presentation by Dr Shilpa Chokshi at the 'Frontiers in Hepatology' meeting held at the Institute of Hepatology, Foundation for Liver Research on 10th October 2017 in London, UK.

Shilpa Chokshi

s.chokshi@researchinliver.org.uk

Antonio Riva

a.riva@researchinliver.org.uk

1 Institute of Hepatology London, Foundation for Liver Research, 111 Coldharbour Lane, London SE5 9NT, UK

2 Faculty of Life Sciences and Medicine, King's College London, London, UK

$\begin{array}{ll}\text { MHC } & \text { Major histocompatibility complex } \\ \text { MAIT } & \text { Mucosa-associated invariant T cells } \\ \text { NK } & \text { Natural killer cells } \\ \text { NKT } & \text { Natural killer T cells } \\ \text { PBMC } & \text { Peripheral blood mononuclear cells } \\ \text { PD-1 } & \text { Programmed death 1 } \\ \text { PD-L1/2 } & \text { Programmed death ligands 1 and 2 } \\ \text { ROS } & \text { Reactive oxygen species } \\ \text { SAH } & \text { Severe alcoholic hepatitis } \\ \text { TIM-3 } & \text { T cell immunoglobulin and mucin domain } 3 \\ \text { HAVCR2 } & \text { Hepatitis A virus cellular receptor 2 } \\ \text { TNF } & \text { Tumor necrosis factor }\end{array}$

\section{Alcoholic liver disease}

Alcoholic liver disease (ALD) is an escalating problem worldwide and is responsible for more than 3 million deaths annually, representing $5.9 \%$ of all deaths globally [1]. Alcohol-attributable deaths vary by continent and 
country, but Europe maintains the global record in terms of prevalence of alcohol consumption [2], with alcohol being responsible for 1 in 7 male deaths and 1 in 13 female deaths in the 15-64 year age group. In the UK alone, liver disease is the third biggest cause of premature mortality in the 18-64 year age group after ischemic heart disease and self-harm, with standardised mortality rates 4-5 times higher since the 1970s [3, 4]. Alcohol abuse also represents one of the strongest risk factors for the development of liver cancer [5], which is $16 \%$ more likely in those who drink heavily ( $>5$ units/day). Cancer Research UK estimates that liver cancer killed 4500 people in the UK in 2012, 3\% of all cancer deaths [5]. Clearly, the potential societal impact of the development of effective therapeutic agents for ALD is far reaching.

There are currently no specific and efficacious therapeutic options for ALD patients, with abstinence being the cornerstone of treatment together with supportive care and liver transplantation currently indicated only for the most severe cases and available in very limited centres worldwide. This is compounded by a widespread reluctance to consider patients with advanced liver disease as candidates for transplantation [6].

Not surprisingly, abstinence is ineffective in completely reversing alcohol-related liver damage in patients who have been long-term excess alcohol abusers and who are at a more advanced and severe stage of disease. In this group, alcohol-related cirrhosis (ARC) is the most common form of established liver disease, which is accompanied by an increased risk of decompensation, organ failure and death. Moreover, high recidivism rates in abstinent patients can lead to repeated presentations of severe alcoholic hepatitis (SAH), the most florid form of ALD, a progressive inflammatory liver condition with a mortality rate of over $30 \%$ at 1 month post-hospitalization $[7,8]$ and approximately $60 \%$ during recidivism [9].

ALD is associated with multiple derangements in host immunity and it is now well-established that ARC induces a state of profound immunodeficiency, known as cirrhosisassociated immunodeficiency syndrome (CAIDS) $[8,10-12]$, which is accompanied by ongoing non-specific systemic inflammation, rendering ARC patients highly susceptible to overwhelming bacterial infections. This increases the risk of organ dysfunction including hepatic encephalopathy, renal failure and circulatory collapse, with no option for liver transplantation acutely [13, 14]. Alcohol abstinence does not fully resolve this, as once the liver is severely injured the deficiency in patients' immunity remains and development of infection significantly compromises their survival chances [15].

Indeed, bacterial infections, sepsis and associated endotoxemia are diagnosed in $25-47 \%$ of hospitalized patients with cirrhosis and represent the most important triggers for acute decompensation and progression to multi-organ failure and septic shock, with short-term mortality of $>75 \%$ [11]. In SAH patients, the susceptibility to bacterial infection is further heightened and infection is observed in nearly $50 \%$ of cases in the short term with a high proportion of them ultimately dying of sepsis [16]. There is increasing evidence that changes in gut permeability, bacterial dysbiosis and translocation of bacteria from the 'leaky' gut into the systemic circulation in ALD is causatively linked to this increase in infections [17].

Current guidelines recommend early antibiotic therapy in these patients and suggest the use of corticosteroids to reduce the systemic inflammation associated with ALD $[7,8,11,16]$. However, the intensive use of antibiotics has caused selection of multi-drug resistant bacteria, with some European centres reporting rates $>20 \%$ [18] and the STOPAH trial has clearly demonstrated lack of benefit with steroid treatment, both short term and long term [19]. Moreover, steroid treatment per se is associated with a further increased susceptibility to infection and sepsis [20].

It is critical to understand why ALD patients have impaired pathogen defence to develop targeted treatments to restore functional immunity. We have previously demonstrated that ALD patients harbour dramatic dysfunctions in their antibacterial defences, affecting both innate and adaptive immune cells (including neutrophils, monocytes, NK cells, T cells and Tregs) and also innatelike subsets (such as NKT cells and MAIT cells), and their responses to bacterial challenge are suboptimal and insufficient $[21,22]$ but reversible. Together, our findings have opened new avenues of research into the immunopathogenesis of ALD and have identified novel potential immunotherapeutic targets for the treatment of this complex disease, in particular the negative immune checkpoint receptors PD-1 and TIM-3 [23, 24]. We believe that hostdirected immunomodulatory therapies aimed at restoring the dysfunctional immunity are a promising approach for the treatment of ALD. In this review, we aim to frame current knowledge on immune checkpoints and the possibility to use checkpoint blockade therapeutically in the context of ALD-associated immune dysfunctions.

\section{Immune responses are implicitly self- limiting}

The immune system has a multitude of implicit mechanisms of self-regulation. Physiologically, these mechanisms promote immune tolerance and control unwanted and excessive injurious immune responses. This maintains immunological homeostasis, preventing immunopathology and limiting excessive inflammation and immune-mediated 
damage. A major arm of this multifaceted immunoregulatory network are the checkpoint receptors, a complex array of membrane receptors and their ligands that act as immune modulators, suppressing or activating key signal transduction pathways and modulating effector cell functions. By doing so, they fine-tune the magnitude, spread and breadth of the immune response, containing it and making it effective (Figs. 1a, 2a). Some of the main negative immune checkpoints that are currently being investigated in cancer, chronic viral infections and sepsis include the PD-1/PD-L1/ PD-L2 pathway, the TIM-3/Galectin-9 pathway, CTLA-4 and LAG-3. However, there is an ever-increasing list of receptors and currently more than 20 endogenous immunoregulatory pathways have been identified and at least partly characterised [25].

Upon acute cell activation, these receptors appear on the cell surface concurrently with the acquisition of a very active functional profile (including secretion of multiple cytokines) [26] and are subsequently downregulated during the immune contraction phase, when the acute insults are resolved, tissue repair and wound healing mechanisms become predominant and immunological memory is
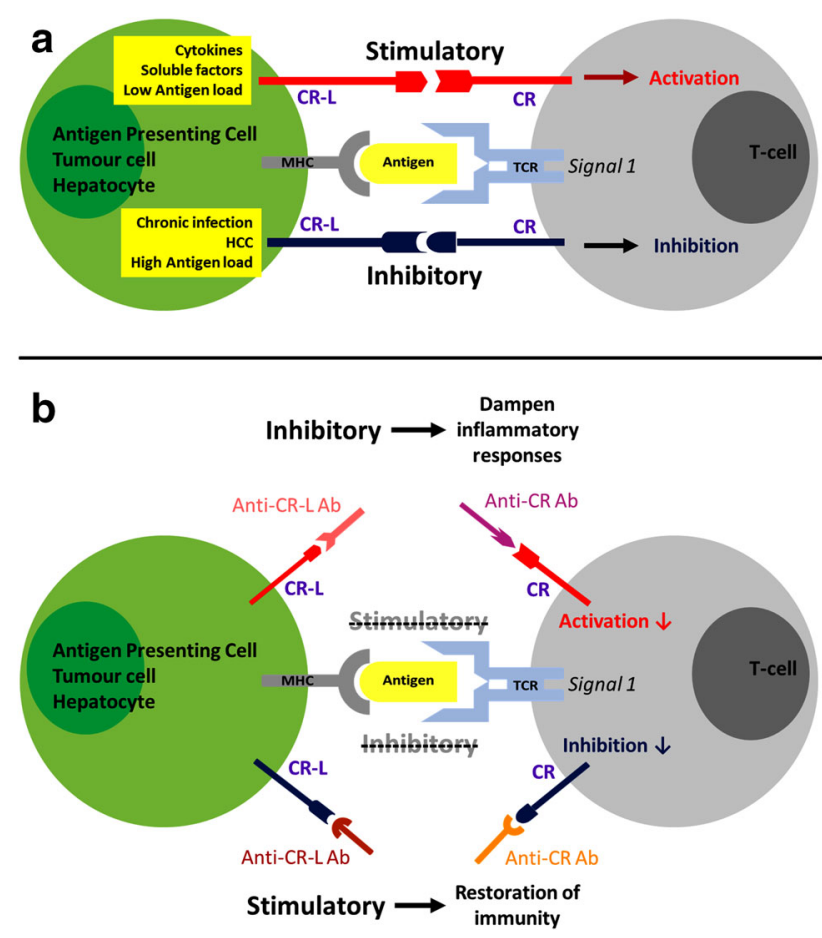

Fig. 1 Immune regulation by checkpoint receptors (CR) and their ligands (CR-L), and effects of immune checkpoint blockade with neutralizing antibodies. Checkpoint receptors modulate the breadth, magnitude and spread of the immune response by balancing stimulatory and inhibitory signals delivered to immune cells by antigen-presenting cells or target cells (a). Blockade of immune checkpoint receptors or their ligands with neutralizing antibodies (Anti-CR Ab and Anti-CR-L Ab) can dampen inflammatory responses and restore dysfunctional immunity (b) consolidated. Instead, during chronic inflammation, chronic infections, cancer or sepsis, characterised by high levels of antigen and proinflammatory cytokines, multiple immunosuppressive checkpoint receptors are persistently hyper-expressed on the cell surface and are continuously activated, chronically suppressing immune cell functions. This phenomenon, called immune "exhaustion", is characterised by a sequential loss of immune activities, including T-cell proliferation, secretion of cytokines and cytotoxic markers, and priming of pro-apoptotic pathways, causing a progressive immune shut-down $[26,27]$. Furthermore, other immunocytes including B cells and NK cells are subjected to similar exhaustion processes, thereby extending the depth of immune suppression to humoral and innate immune responses [28-32]. The patients' overly active immune system thus contains immunopathology and preserves the structural and functional integrity of tissues and organs but becomes unable to mount strong, effective and coordinated anti-pathogen responses (Fig. 2b). This favours susceptibility to infection, especially with opportunistic pathogens, similar to what we observe in septic patients and in ARC/SAH patients [10, 11, 33-35]. Immune functions remain persistently deranged for years after the resolution of the first septic episode in septic survivors and even after years of alcohol abstinence in ARC/SAH patients [15]. This is directly linked to persistently high expression of negative immune checkpoints [34].

Different immune checkpoints display different anatomical and temporal patterns of expression. The kinetics of immune checkpoint expression are highly regulated and coordinated and the dynamic interplay between stimulatory receptors (such as CD28, CD80 and CD86) and inhibitory checkpoints (e.g., PD-1, PD-L1, TIM-3) during cellular activation defines the evolution and fate of the existing immune response.

\section{The PD-1 and TIM-3 pathways}

The PD-1 pathway belongs to the CD28/B7 family of T-cell co-receptors. PD-1/CD279 is probably the most studied checkpoint receptor in the field of T-cell exhaustion. This receptor was first identified in apoptotic T-cell lines (hence the name "programmed death 1") but was soon characterised as a negative immunoregulator [36-39]. PD-1 has two known ligands, namely PD-L1/B7-H1/ CD274 and PD-L2/B7-DC/CD273 [40-43]. PD-L1 is ubiquitously expressed at low levels and is strongly induced by proinflammatory signals [44, 45], while PD-L2 displays a more restricted expression profile [43, 46, 47]. Upon engagement, PD-1 sequesters intracellular factors involved in the TCR signalling, stopping T-cell activation [40-43]. PD-1/PD-L1 signalling appears to be 
Fig. 2 Increased expression of inhibitory checkpoint receptors suppresses homeostatic immunity and checkpoint blockade restores a healthy state. The homeostatic balance between anti-pathogen immunity and host-induced immunopathology is maintained in physiological conditions; this maintains a healthy immune state (a). Upon chronic stimulation, inhibitory checkpoints are hyperexpressed, limiting uncontrolled responses and immunemediated damage but simultaneously suppressing efficient anti-pathogen responses (b). Blockade of inhibitory checkpoints can suppress these hyper-inhibitory signals, restoring a healthy immune state $(\mathbf{c})$ a

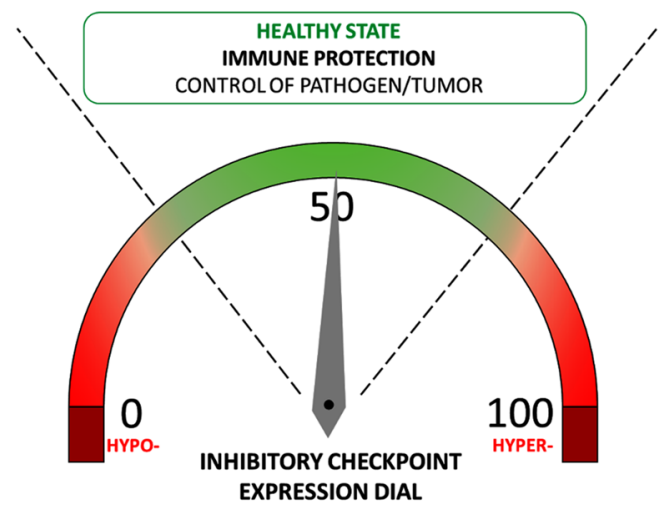

b

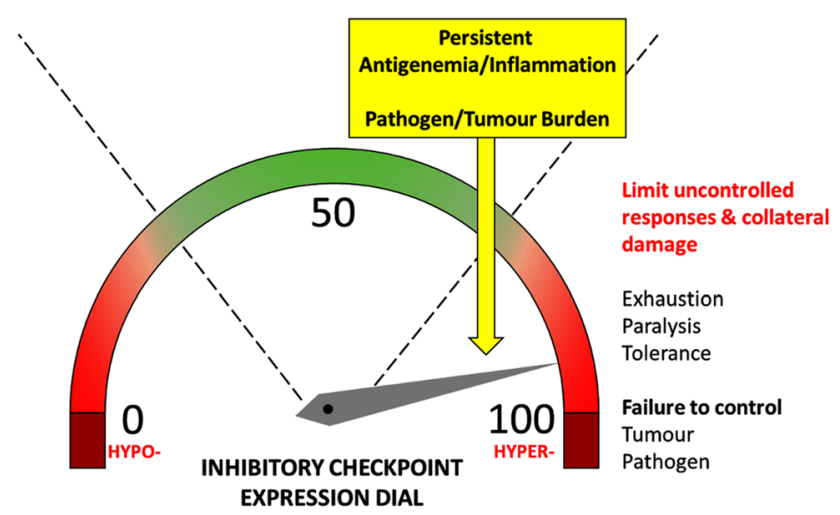

C

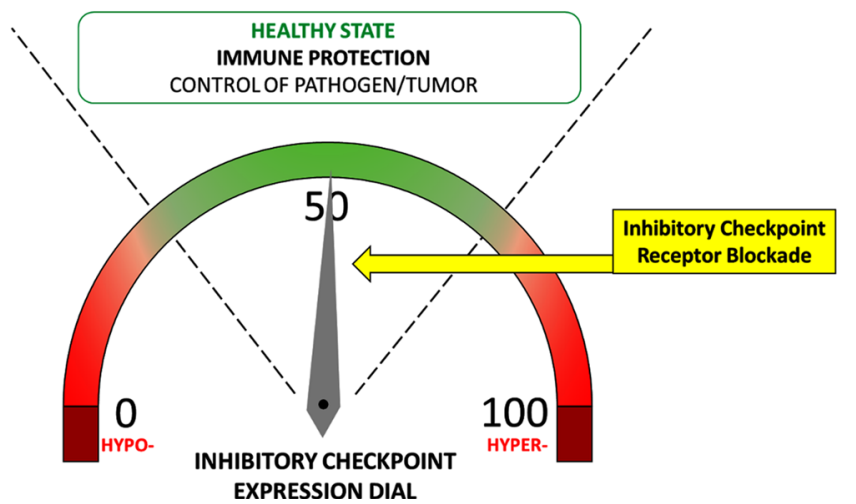

for instance, is well-described [28, 29] and PD-1 expression on NK cells has also been linked to NK-cell functional suppression [31, 32]. In a study investigating immune exhaustion in HIV patients, contact with bacterial products induced monocyte expression of PD-1 and these monocytes secreted suppressive IL-10 upon PD-1 engagement. Furthermore, T-cell exhaustion in these patients could be reversed by blocking either PD-1 or IL-10 receptor [55]. Monocyte activation by bacterial endotoxin was also shown to physiologically cause increased secretion of suppressive IL-10 and upregulation of PD-1 and TIM-3 on $\mathrm{T}$ cells, and simultaneous blockade of TLR4 and CD14 abolished IL-10 secretion and inhibited T-cell checkpoint upregulation [21]. These findings link the PD-1 pathway to 
the regulation of antibacterial immunity, which is key in ALD patients.

TIM-3/CD366 was first described as a marker of activated IFN $\gamma$-producing $\mathrm{T}$ cells [56]. TIM-3 binds to Galectin-9 causing suppression of cytokine production, cell cycle arrest and even cell death [57, 58]. TIM-3 is widely expressed on several tissues and is promptly upregulated on $\mathrm{T}$ cells in response to both TCR-dependent and TCR-independent stimulation by common-gamma-chain cytokines (IL-2/7/15/21) [58-60]. Galectin-9 is widely expressed and is further induced by proinflammatory cytokines [61]. TIM-3 is important for T-cell exhaustion both in chronic viral infections [62-64] and in cancer [65-67]. TIM-3 is often co-expressed with PD-1 on severely exhausted T cells [25], where both receptors act synergistically to suppress immune functions [68, 69] and it has been demonstrated that blockade of TIM-3 partially restores these impaired T-cell functions [58, 66, 70]. However, there are still unanswered questions regarding paradoxical effects of the TIM-3 pathway observed in bacterial infection, for instance in tuberculosis where activation of this pathway seems to favour immune activation and disease control [71-73] but also suppression of T-cell functions and disease persistence [74]. Patients with SAH compared to healthy individuals display increased plasma Galectin-9 and higher TIM-3 expression on several immune subsets, together with production of suppressive IL-10 and reduced antibacterial functions, suggesting activation of the TIM-3 pathway in these patients [21].

\section{CTLA-4 and LAG-3}

CTLA-4/CD152 is another member of the CD28/B7 family of T-cell co-receptors and is the first negative immune checkpoint studied in depth. CTLA-4 binds to CD80 and CD86 with approximately 20 times greater affinity than CD28 [40, 75], competing for CD80/CD86 binding and lowering the probability of T-cell costimulation by preventing activating interactions with APCs. Second, upon engagement the cytoplasmic tail of CTLA-4 sequesters factors involved in the TCR signalling, shutting down TCR-mediated T-cell activation [54, 76, 77]. Furthermore, CTLA-4 binding with CD80/CD86 can induce transendocytosis, effectively removing $\mathrm{B} 7$ molecules from the surface of APCs [78]. CTLA-4 can act bidirectionally, inducing the production of immunosuppressive IDO by APCs, which metabolically inhibits bystander T-cell functions [51]. CTLA-4 can also bind to another B7 family member called B7-H2, which is the only known ligand for the activatory receptor ICOS, possibly preventing ICOSmediated T-cell costimulation [79]. Amongst $\mathrm{T}$ cells, CTLA-4 expression is stronger in naïve $\mathrm{T}$ cells and Tregs, and therefore it is believed that CTLA-4 in comparison to
PD-1 may be more relevant in the initial phases of immune activation, preventing immune priming and the establishment/maintenance of central tolerance [54].

LAG-3/CD223 is a molecular homolog of CD4 [80], first described as a regulator of Treg activity [81]. LAG-3 binds uniquely to MHC-II molecules, which are upregulated during inflammation. The exact mechanisms of action of LAG-3 are still unclear. LAG-3 is strongly expressed on anergic and on exhausted $\mathrm{T}$ cells, often in strong association with PD-1 [82, 83]. Neutralizing antibodies against LAG-3 can only partially reverse anergy and rescue immune dysfunction [54, 84], but combined anti-LAG-3/ PD-1 approaches have demonstrated stronger immune restoration [85], suggesting that LAG-3 inhibitory activity alone may be gentler than other inhibitory checkpoints.

\section{Immune checkpoints and checkpoint blockade in diseases}

\section{Viral infections}

Many pathogens have developed strategies to exploit immune checkpoint regulation as a way to facilitate immune escape/masking. For instance, viruses such as HIV, HCV and HBV, which establish chronic infections in humans, have evolved the ability to manipulate the PD-1 pathway to favour viral persistence [86-92]. In patients with chronic $\mathrm{HBeAg}+\mathrm{HBV}$ infection, for example, we previously found dramatic $\mathrm{T}$-cell dysfunctions associated with upregulation of PD-1 on virus-specific T cells [93]. PD-1 expression correlated directly with viremia and decreased progressively during antiviral treatment. In these patients, $\mathrm{T}$ cells displayed a skewed cytokine production with lack of antiviral IFN $\gamma$ and predominant suppressive IL-10. During antiviral treatment, $\mathrm{HBeAg}+$ patients who achieved $\mathrm{HBeAg}$ seroconversion, which requires the presence of immunologically active $\mathrm{T}$ cells, appeared to be those with a more prominent loss of T-cell PD-1, suggesting immune reactivation, and the decreased PD-1 expression was accompanied by normalisation of cytokine production and IFN $\gamma / \mathrm{IL}-10$ ratio. Higher expression of PD1 on $\mathrm{HBV}$-specific T cells has also been linked to failure to spontaneously eradicate the virus during acute infections, determining an immune milieu favourable to viral persistence [90, 94], while increased expression of PD-1 on B cells has been linked to $\mathrm{B}$ cell functional suppression in HIV infection [28, 29]. Blockade of the PD-1 pathway has been suggested as a possible host-targeted strategy to reactivate antiviral immunity and immune-mediated viral control in HBV, HIV or HCV infections (Figs. 1b, 2c) [86-92]. 


\section{Cancer}

Blockade of negative checkpoints first received FDA approval in the context of anticancer treatments [54]. The tumor microenvironment expresses high levels of negative checkpoints and their ligands, which translates into a strong local suppression of anticancer responses. For instance, cancer cells of different origins express high levels of PDL1 and IDO [95-100], either as a direct effect of cancerrelated intracellular pathways $[101,102]$ or as a result of IFN $\gamma$ stimulation by infiltrating immune cells [103-107]. Therefore, they can suppress tumor-infiltrating cancerspecific $T$ cells by PD-1 engagement and by depleting the local milieu of essential tryptophan metabolites. Additionally, tumor-infiltrating lymphocytes have high expression of multiple checkpoint markers, with increasing numbers of receptors correlated to the severity of immune impairment [26]. Lastly, PD-1 is not only expressed on tumor-infiltrating T cells, but also on NK and B cells [54], suggesting a farther-reaching effect for a broader immune modulation.

In vitro checkpoint receptor blockade has demonstrated efficacy at rescuing exhausted tumor-specific $\mathrm{T}$ cells, favouring increased breadth and magnitude of effector functions and T-cell survival (Figs. 1b, 2c) [108] and an increasing number of clinical trials for new anticancer treatments based on immune checkpoint blockade are showing objective therapeutic responses in several patients, limiting disease progression and in some cases arresting or even reverting tumor growth. The most studied pathway in this context has been the B7 pathway [54, 109-112].

In pre-clinical studies, anti-CTLA-4 treatment showed successful reactivation of pre-existent anti-tumor immunity, alone or in combination with other immunomodulatory agents (such as GM-CSF) [54]. In clinical trials, treatment of melanoma with the FDA-approved antiCTLA-4 antibody ipilimumab improved clinical outcome and survival both short term and long term, with relatively contained immune-related adverse events [113-116].

In a number of pre-clinical studies, PD-1/PD-L1 expression in the tumor microenvironment has been linked to immune dysfunction and PD-1/PD-L1 blockade has achieved immune rescue [54]. Clinically, anti-PD-1 and anti-PD-L1 have been tested in several cancers displaying good outcomes and a relatively good safety profile $[111,112]$. The anti-PD-1 antibodies nivolumab and pembrolizumab have demonstrated better safety profiles and far greater success rates in comparison to current standard treatments (such as sorafenib to treat advanced hepatocellular carcinoma, HCC) [110] and also in comparison to anti-CTLA-4 strategies [54] in several clinical trials for different cancers $[111,117,118]$. In the
'CheckMate 040' trial for the use of nivolumab (humanised anti-PD-1 antibody) in advanced HCC $20 \%$ of patients had an objective response (OR), and up to $64 \%$ of them achieved disease control (DC), compared to $<1 \% \mathrm{OR}$ and $43 \% \mathrm{DC}$, respectively, with sorafenib as standard treatment [110, 119]. PBMC and plasma/serum samples from the 'CheckMate 040' patients are being collected and stored in our laboratories and currently used to investigate a robust biomarker of treatment response in this cohort.

Inhibitory checkpoint antibodies are currently being tested alone or in combination with other neutralizing antibodies in cancer to achieve a stronger immune reconstitution by blocking several checkpoint receptors at once [54]. Inhibitory checkpoint antibodies currently in clinical development or tested in clinical trials as new anticancer agents are illustrated in Fig. 3 [120-124].

\section{Sepsis and septic shock}

According to the Third International Consensus Definitions for Sepsis and Septic Shock (Sepsis-3), sepsis is a "lifethreatening organ dysfunction caused by a dysregulated host response to infection (...) that arises when the body's response to an infection injures its own tissues and organs" and septic shock is a "subset of sepsis in which particularly profound circulatory, cellular, and metabolic abnormalities are associated with a greater risk of mortality than with sepsis alone" [35]. The original biphasic description of sepsis and septic shock included a first phase during which an overwhelming systemic inflammatory response would develop upon pathogen detection (systemic inflammatory response syndrome, SIRS), characterised by uncontrolled immune activation, cytokine storm and the occurrence of immune-mediated tissue and organ damage, with potentially lethal consequences. A second phase would then ensue during which the hyper-active SIRS response would subside and compensatory anti-inflammatory mechanisms would complete pathogen clearance and tissue repair (compensatory anti-inflammatory response syndrome, CARS) [125-127], characterised by the induction of physiological mechanisms of immune shut-down and the activation of the healing response, with the acquisition of a strong endogenous immunosuppressed state. The current description of sepsis, however, has changed. It is now clear that SIRS and CARS are not two distinct sequential entities and the immune derangement that occurs during sepsis represents the contrasting combination of concurrent immune activation and immune exhaustion, where a state of persistent immunosuppression arises in parallel with the initial immune activation and drives the underlying immune dysfunction long term [128-132]. Indeed, septic patients who survive the initial inflammatory phase of sepsis present with an increased susceptibility to secondary 


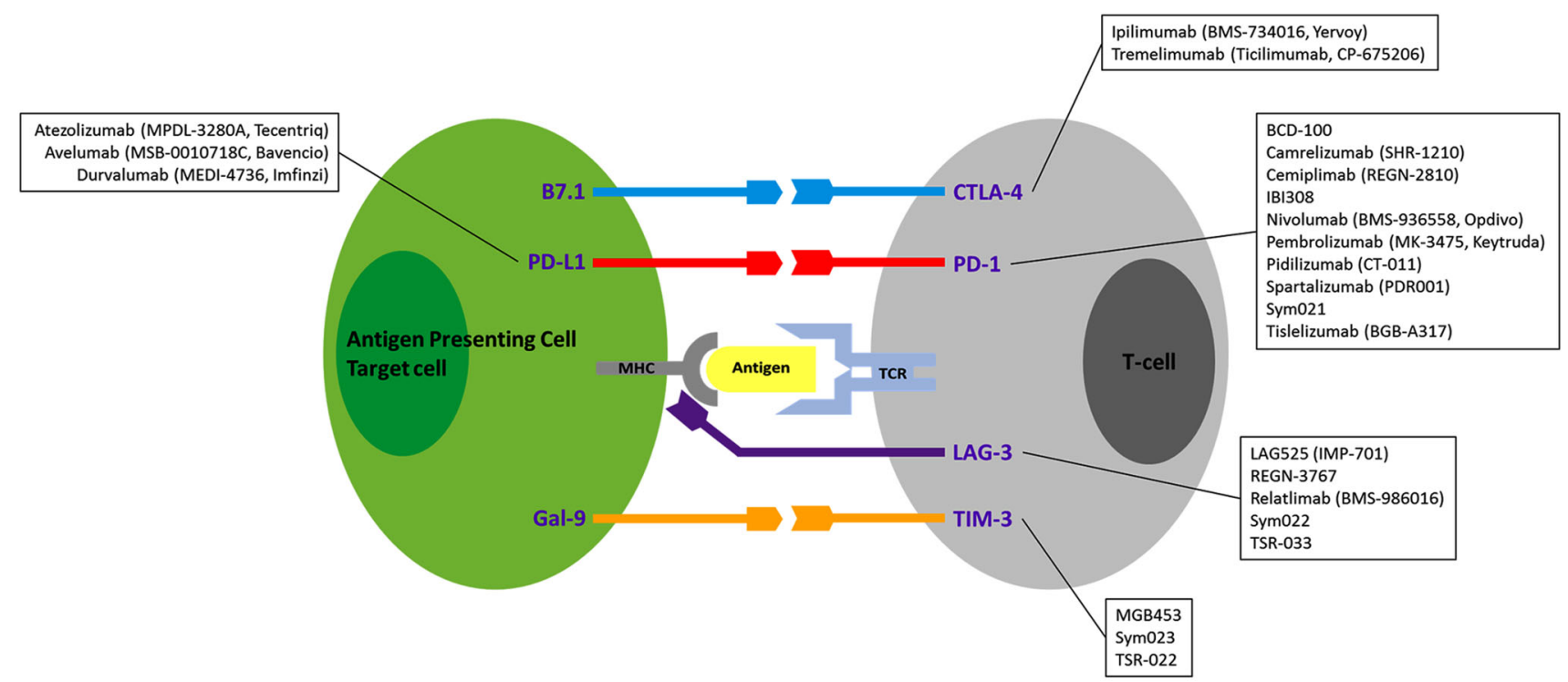

Fig. 3 Immune checkpoints as therapeutic targets. Monoclonal antibodies currently in clinical development or tested in clinical trials against CTLA-4, PD-1, PD-L1, LAG-3 and TIM-3, as new anticancer

opportunistic infections long term, indicating that immunosuppression and immune impairments are maintained over time [133, 134]. Immunosuppression rather than hyper-immunity drives the response to sepsis, as also supported by the evidence that clinical trials focussed on reducing hyper-immunity/SIRS have provided conflicting and disappointing results [135-138].

Negative immune checkpoints (including PD-1, PD-L1, TIM-3, CTLA-4, LAG-3 and others) play a causal role in this persistent immunosuppression [139-143]. Their expression on both innate and adaptive immune cells is greatly increased in septic patients, correlating with loss of immune functions (including innate antibacterial activities from monocytes, macrophages or neutrophils and T-cell production of cytokines and cytotoxic factors), immune cell apoptosis, reduced pathogen clearance and increased patient mortality [34, 141, 143-146]. Most of these immune dysfunctions can be at least partially restored by blocking checkpoint pathways (Figs. 1b, 2c) [34]. This strategy is currently being investigated in several preclinical and clinical ex vivo studies with promising results in septic patients, suggesting that host-targeted immunotherapy may rescue suppressed antimicrobial immunity, reduce susceptibility to infection and improve patient survival [34]. The first clinical trial to determine the safety profile and efficacy of treatment with the anti-PD-1 antibody nivolumab in patients with severe sepsis or septic shock has been completed (NCT02960854), and results of this trial are eagerly awaited. agents, as these same immune checkpoint antibodies also represent the most promising therapeutic agents for future clinical trials in ALD

\section{Immune checkpoints and checkpoint blockade in ALD}

Many features of sepsis and septic shock resemble those observed in ALD patients who acquire bacterial infection. This is particularly pertinent in the context of severe ALD, including decompensated cirrhosis, alcohol-related liver failure, alcohol-related acute-on-chronic liver failure (ACLF) and SAH. Furthermore, in abstinent patients immune defects persist over a long term, a common feature with sepsis survivors. Hence, there may be a strong parallelism between mechanisms of immune dysfunction in sepsis and those at play in ALD. As discussed, several studies have investigated the contribution of negative immune checkpoints to the immunopathophysiology of sepsis and several pre-clinical and clinical studies are defining the parameters of immune checkpoint blockade as a therapeutic strategy in these patients. However, no such clinical investigations exist in the context of ALD, highlighting a large gap in the possibility to develop new hosttargeted strategies for ALD and its complications, for which there are no current specific treatment options.

In a 2015 study, we performed an in-depth ex vivo immunological characterisation of antibacterial responses in ARC and SAH patients and we were the first group to show that immune dysfunctions observed in SAH patients relate directly to increased expression of PD-1 and TIM-3 on several immune subsets [21]. Immune alterations were directly correlated with severity of disease, and gut-derived bacterial products were driving these immune dysfunctions, therefore highlighting a parallel with bacterial sepsis. 
First, we observed that neutrophils had reduced bacterial phagocytosis and increased non-specific ROS production, which may cause bystander tissue damage in the inflamed liver. Furthermore, when challenged with bacterial cells and antigens, neutrophils were unable to mount an oxidative response, indicating a defect in antibacterial innate functions.

Upon bacterial stimulation, we observed that antibacterial responses were predominantly immunosuppressive in SAH patients, with less IFN $\gamma$-producing and more IL-10producing cells compared to healthy individuals. This immune imbalance was directly correlated with increased expression of PD-1 and TIM-3 on both CD4 and CD8 T cells and, in addition, plasma levels of TIM-3 ligand Galectin-9 were increased in SAH patients. PD-1 and TIM3 were also increased on NK and NKT cells. It remains unclear whether PD-1 and TIM-3 or checkpoint receptors in general have a role in modulating humoral responses in ALD.

When we investigated the causes of PD-1/TIM-3 hyperexpression we found that both ethanol alone and stimulation with bacterial endotoxin dose-dependently upregulated both immune checkpoints on CD4, CD8 T cells and Tregs. The effects of ethanol and endotoxin were additive, and skewed cytokine production preferentially towards IL-10 production.

Since monocytes are amongst the most endotoxin-responsive immune cells, we performed blocking experiments directed at suppressing TLR4/CD14 signalling, and we observed that combined blockade of both endotoxin receptors abolished IL-10 and TNF $\alpha$ monocyte production upon bacterial challenge and above all completely prevented PD-1/TIM-3 upregulation on CD4 and CD8 T cells.

Most importantly, blockade of PD-1 and TIM-3 in endotoxin-stimulated PBMCs restored IFN $\gamma$ and reduced IL-10 production in SAH patients, re-establishing an appropriate IFN $\gamma / \mathrm{IL}-10$ balance. Furthermore, checkpoint blockade increased the phagocytic and oxidative neutrophil response to bacterial challenge, suggesting that immune dysfunctions in ALD patients are not permanent but reversible and that immune checkpoint blockade may be useful to restore defective antibacterial immunity in ALD patients, especially in SAH patients.

The involvement of the PD-1 pathway in causing skewed IL-10 production and pathogenic immunosuppression is already known in patients with non-alcoholic sepsis, where endotoxin-driven IL-10 production and IFN $\gamma$ suppression can be reversed by therapeutic PD-1/PD-L1 blockade, with improved bacterial clearance and reduced patient mortality [147, 148]. Endotoxin levels in the liver are higher compared to the periphery [149] and liver inflammation correlates with intrahepatic expression of PD-1/PD-L1 [150]. Interestingly, in mouse models of sepsis blockade of the PD-1 pathway reduced liver inflammation and increased survival [148, 151].

In our study, immune reconstitution driven by in vitro PD-1/TIM-3 blockade was not accompanied by exacerbation of inflammatory markers (including IL-1 $\beta / 6 / 8$, TNF $\alpha$ and IP-10, which are linked to immunopathology in SAH) and did not increase spontaneous ROS production in neutrophils, suggesting that immune checkpoint blockade may be a safe therapeutic approach in ALD [21]. Anti-checkpoint antibodies currently used for therapeutic purposes in cancer and sepsis have good safety profiles, with low occurrence of severe adverse events, and it could be argued that good safety profiles may be maintained when these treatment strategies are extended to ALD.

\section{Risks of checkpoint receptor therapy, biomarkers and new developments}

Immunotherapy with inhibitory checkpoint blockade raises the possibility of skewing immunity towards an injurious hyper-active response, with increased inflammation and loss of immune tolerance, resulting in immune-related adverse events (irAEs). Moreover, breaking tolerance in patients who already harbor severe immune dysfunction, such as advanced ALD patients, may further exacerbate this risk.

In our study we did not observe exacerbation of inflammatory markers following immune checkpoint blockade ex vivo, as described earlier [21]. No information is currently available on irAEs derived from immune checkpoint blockade in sepsis and septic shock, as the NCT02960854 clinical trial remains unpublished at the time of writing, but in the context of liver studies, the majority of irAEs reported in the 'CheckMate 040' clinical trial for the treatment of hepatocellular carcinoma with the anti-PD-1 antibody nivolumab were mild (mainly dermatological and gastrointestinal; $75 \%$ below grade 3 ), with low occurrence of severe irAEs $(6 \%)$ and no treatmentrelated deaths [110]. Overall, the 'CheckMate 040' safety results are in line with most studies reviewing the occurrence of irAEs following immune checkpoint blockade [152, 153].

The development of irAEs clearly indicates that blocking inhibitory checkpoint pathways is effective at reactivating a dormant immune system. Conversely, a heightened state of immunity and inflammation can also have an effect on checkpoint blockade responses. In fact, it has been suggested that pre-existing autoimmune conditions may render some patients more susceptible to developing irAEs, although it is still unclear whether irAEs correlate with successful treatment response $[152,153]$. On the other hand, some patients are refractory to treatments 
using checkpoint blocking antibodies, which has been linked, for example, to defective antigen presentation to effector $\mathrm{T}$ cells, greater $\mathrm{T}$-cell exhaustion and $\mathrm{T}$-cell expression of a broader array of inhibitory checkpoints or enhanced proinflammatory signalling via interferon responsive elements [154-156].

Overall, accurate patient selection is a key. Objective responses to immune checkpoint-based treatments are expected to be at least partly dependent on the presence of pre-existing checkpoint-driven immune dysfunctions and on the expression of high levels of checkpoint receptors in the first place. Meta-analyses of checkpoint blockade treatment in cancer have clearly shown this to be the case and that, for instance, higher expression levels of PD-L1 by the tumor microenvironment are associated with better response to anti-PD-1 treatment and lower occurrence of adverse events in a variety of cancers [157, 158], although agreement on this topic is not absolute [159, 160]. Regardless, monitoring levels of immune checkpoint expression prior to initiating treatment may provide additional indications for a more accurate selection of patients who are more likely to have a response without developing immunopathology [157, 158].

A further complication resides in the fact that immune checkpoint receptors and their ligands can also exist in soluble form [161]. Proposed mechanisms involved in the generation of these soluble forms include alternative mRNA splicing or protease-mediated shedding and it is still unclear which mechanism prevails for which specific immune checkpoint [161]. Similarly, it is unclear how soluble immune checkpoints act, whether they are partial or full agonists for their membrane-bound ligands, or rather simple antagonist decoys for each other or for their membrane-bound counterparts [161]. The presence of soluble checkpoints has been demonstrated in several disorders, often in correlation with disease severity and response to treatment, but current studies are far from providing conclusive results [162-169]. Soluble checkpoint receptors and ligands may be ideal candidate diagnostic and prognostic biomarkers and it will be interesting to investigate if and how they affect response to checkpoint blockade treatment and in particular if and how they can be a priori predictors of positive outcome [170].

\section{Perspectives and conclusions}

The immune checkpoint system is a very complex and exquisitely fine-tuned endogenous network of immune regulation. The balance between protective immunity and immune tolerance on one side and immunopathology and autoimmunity on the other relies on a dynamic homeostatic equilibrium between co-stimulatory signals and a comparatively larger number of inhibitory pathways, which can be easily skewed causing strong and persistent immunosuppression during chronic inflammatory diseases. Chronic infection, cancer, sepsis and ALD present with partly overlapping immune profiles, characterised by hyper-expression of inhibitory checkpoint pathways on several subsets of immune cells and consequent innate and adaptive immune defects, which depending on the disease will favour immune escape, immune masking or inability to contend with secondary infections. Novel host-targeted therapies based on blocking negative immune checkpoints are efficacious and have good safety profiles in cancer treatment and are being tested to resolve persistent immunosuppression in septic patients. We have been the first to describe a role for PD-1 and TIM-3 in the immunopathogenesis of ALD and we believe that these and other membrane and soluble immune checkpoints will represent novel potential prognostic markers and safe therapeutic targets for the treatment of ALD.

Author contributions AR wrote/revised the paper. SC revised the paper. Both authors reviewed and approved the final version of the paper.

Funding This study was funded by the Foundation for Liver Research.

\section{Compliance with ethical standards}

Conflict of interest We have no conflict of interest to declare.

Open Access This article is distributed under the terms of the Creative Commons Attribution 4.0 International License (http://creative commons.org/licenses/by/4.0/), which permits unrestricted use, distribution, and reproduction in any medium, provided you give appropriate credit to the original author(s) and the source, provide a link to the Creative Commons license, and indicate if changes were made.

\section{References}

1. WHO. Global status report on alcohol and health 2014. World Health Organization; 2014. ISBN 9789240692763

2. WHO. European status report on alcohol and health 2010. World Health Organization; 2010. ISBN 9789289002066

3. Williams R, Aspinall R, Bellis M, Camps-Walsh G, Cramp M, Dhawan A, et al. Addressing liver disease in the UK: a blueprint for attaining excellence in health care and reducing premature mortality from lifestyle issues of excess consumption of alcohol, obesity, and viral hepatitis. Lancet Lond Engl 2014;384(9958):1953-1997

4. Williams R, Alexander G, Aspinall R, Bosanquet J, CampsWalsh G, Cramp M, et al. New metrics for the Lancet Standing Commission on Liver Disease in the UK. Lancet 2017;389(10083):2053-2080 
5. Cancer Research UK. Liver cancer statistics. Cancer Research UK. 2015. http://www.cancerresearchuk.org/health-professional/ cancer-statistics/statistics-by-cancer-type/liver-cancer. Accessed 24 Jan 2018

6. Cohen C, Benjamin M. Alcoholics and liver transplantation. The Ethics and Social Impact Committee of the Transplant and Health Policy Center. JAMA 1991;265(10):1299-1301

7. European Association for the Study of Liver. EASL clinical practical guidelines: management of alcoholic liver disease. J Hepatol 2012;57(2):399-420

8. Louvet A, Mathurin P. Alcoholic liver disease: mechanisms of injury and targeted treatment. Nat Rev Gastroenterol Hepatol 2015;12(4):231-242

9. Potts JR, Howard MR, Verma S. Recurrent severe alcoholic hepatitis: clinical characteristics and outcomes. Eur J Gastroenterol Hepatol 2013;25(6):659-664

10. Albillos A, Lario M, Álvarez-Mon M. Cirrhosis-associated immune dysfunction: Distinctive features and clinical relevance. J Hepatol 2014;61(6):1385-1396

11. Jalan R, Fernandez J, Wiest R, Schnabl B, Moreau R, Angeli P, et al. Bacterial infections in cirrhosis: a position statement based on the EASL Special Conference 2013. J Hepatol 2014;60(6): 1310-1324

12. Bonnel AR, Bunchorntavakul C, Reddy KR. Immune dysfunction and infections in patients with cirrhosis. Clin Gastroenterol Hepatol Off Clin Pract J Am Gastroenterol Assoc 2011;9(9):727-738

13. Wong F, Bernardi M, Balk R, Christman B, Moreau R, GarciaTsao G, et al. Sepsis in cirrhosis: report on the 7th meeting of the International Ascites Club. Gut 2005;54(5):718-725

14. Shawcross DL, O'Grady JG. The 6-month abstinence rule in liver transplantation. Lancet 2010;376(9737):216-217

15. Eggers V, Pascher A, Althoff H, Thiele S, Mütze J, Selignow J, et al. Immune reactivity is more suppressed in patients with alcoholic liver disease than in patients with virus-induced cirrhosis after CRH stimulation. Alcohol Clin Exp Res 2006;30(1):140-149

16. Louvet A, Wartel F, Castel H, Dharancy S, Hollebecque A, Canva-Delcambre $\mathrm{V}$, et al. Infection in patients with severe alcoholic hepatitis treated with steroids: early response to therapy is the key factor. Gastroenterology 2009;137(2):541-548

17. Hartmann P, Chen W-C, Schnabl B. The intestinal microbiome and the leaky gut as therapeutic targets in alcoholic liver disease. Gastrointest Sci 2012;3:402

18. Fernández J, Bert F, Nicolas-Chanoine M-H. The challenges of multi-drug-resistance in hepatology. J Hepatol 2016;65(5):1043-1054

19. Thursz MR, Richardson P, Allison M, Austin A, Bowers M, Day $\mathrm{CP}$, et al. Prednisolone or pentoxifylline for alcoholic hepatitis. N Engl J Med 2015;372(17):1619-1628

20. Vergis N, Atkinson SR, Knapp S, Maurice J, Allison M, Austin $\mathrm{A}$, et al. In patients with severe alcoholic hepatitis, prednisolone increases susceptibility to infection and infection-related mortality, and is associated with high circulating levels of bacterial DNA. Gastroenterology 2017;152(5):1068-1077.e4

21. Markwick LJL, Riva A, Ryan JM, Cooksley H, Palma E, Tranah $\mathrm{TH}$, et al. Blockade of PD1 and TIM3 restores innate and adaptive immunity in patients with acute alcoholic hepatitis. Gastroenterology 2015;148(3):590-602.e10

22. Riva A, Patel V, Kurioka A, Jeffery HC, Wright G, Tarff S, et al. Mucosa-associated invariant $\mathrm{T}$ cells link intestinal immunity with antibacterial immune defects in alcoholic liver disease. Gut 2018;67(5):918-930

23. Bataller R, Mandrekar P. Identifying molecular targets to improve immune function in alcoholic hepatitis. Gastroenterology $2015 ; 148(3): 498-501$
24. Gao B, Ma J, Xiang X. MAIT cells: a novel therapeutic target for alcoholic liver disease? Gut 2018;67(5):784-786

25. Chen L, Flies DB. Molecular mechanisms of T cell co-stimulation and co-inhibition. Nat Rev Immunol 2013;13(4):227-242

26. Legat A, Speiser DE, Pircher H, Zehn D, Fuertes Marraco SA. Inhibitory receptor expression depends more dominantly on differentiation and activation than "Exhaustion" of human CD8 T cells. Front Immunol 2013;4:455

27. Kahan SM, Wherry EJ, Zajac AJ. T cell exhaustion during persistent viral infections. Virology 2015;479-480:180-193

28. Moir S, Fauci AS. B-cell exhaustion in HIV infection: the role of immune activation. Curr Opin HIV AIDS 2014;9(5):472-477

29. Boliar S, Murphy MK, Tran TC, Carnathan DG, Armstrong WS, Silvestri G, et al. B-lymphocyte dysfunction in chronic HIV-1 infection does not prevent cross-clade neutralization breadth. J Virol 2012;86(15):8031-8040

30. Goodman A, Patel SP, Kurzrock R. PD-1-PD-L1 immunecheckpoint blockade in B-cell lymphomas. Nat Rev Clin Oncol 2017;14(4):203-220

31. Beldi-Ferchiou A, Caillat-Zucman S. Control of NK cell activation by immune checkpoint molecules. Int $\mathrm{J}$ Mol Sci. 2017;18(10):2129

32. Muntasell A, Ochoa MC, Cordeiro L, Berraondo P, López-Díaz de Cerio A, Cabo M, et al. Targeting NK-cell checkpoints for cancer immunotherapy. Curr Opin Immunol 2017;45:73-81

33. Sipeki N, Antal-Szalmas P, Lakatos PL, Papp M. Immune dysfunction in cirrhosis. World $\mathrm{J}$ Gastroenterol WJG 2014;20(10):2564-2577

34. Patil NK, Guo Y, Luan L, Sherwood ER. Targeting immune cell checkpoints during sepsis. Int J Mol Sci 2017;18(11):2413

35. Singer M, Deutschman CS, Seymour CW, Shankar-Hari M, Annane D, Bauer M, et al. The third international consensus definitions for sepsis and septic shock (Sepsis-3). JAMA 2016;315(8):801-810

36. Finger LR, Pu J, Wasserman R, Vibhakar R, Louie E, Hardy RR, et al. The human PD-1 gene: complete cDNA, genomic organization, and developmentally regulated expression in $\mathrm{B}$ cell progenitors. Gene 1997;197(1-2):177-187

37. Nishimura H, Nose M, Hiai H, Minato N, Honjo T. Development of lupus-like autoimmune diseases by disruption of the PD-1 gene encoding an ITIM motif-carrying immunoreceptor. Immunity 1999;11(2):141-151

38. Nishimura H, Okazaki T, Tanaka Y, Nakatani K, Hara M, Matsumori A, et al. Autoimmune dilated cardiomyopathy in PD1 receptor-deficient mice. Science 2001;291(5502):319-322

39. Berger KN, Pu JJ. PD-1 pathway and its clinical application: a 20 year journey after discovery of the complete human PD-1 gene. Gene 2018;638:20-25

40. Kim ES, Kim JE, Patel MA, Mangraviti A, Ruzevick J, Lim M. Immune checkpoint modulators: an emerging antiglioma armamentarium. J Immunol Res 2016;2016:4683607

41. Parry RV, Chemnitz JM, Frauwirth KA, Lanfranco AR, Braunstein I, Kobayashi SV, et al. CTLA-4 and PD-1 receptors inhibit T-cell activation by distinct mechanisms. Mol Cell Biol 2005;25(21):9543-9553

42. Freeman GJ, Long AJ, Iwai Y, Bourque K, Chernova T, Nishimura $\mathrm{H}$, et al. Engagement of the PD-1 immunoinhibitory receptor by a novel $\mathrm{B} 7$ family member leads to negative regulation of lymphocyte activation. J Exp Med 2000;192(7):1027-1034

43. Latchman Y, Wood CR, Chernova T, Chaudhary D, Borde M, Chernova I, et al. PD-L2 is a second ligand for PD-1 and inhibits T cell activation. Nat Immunol 2001;2(3):261-268

44. Petroff MG, Chen L, Phillips TA, Hunt JS. B7 family molecules: novel immunomodulators at the maternal-fetal interface. Placenta 2002;23(Suppl A):S95-S101 
45. Spranger S, Spaapen RM, Zha Y, Williams J, Meng Y, Ha TT, et al. Up-regulation of PD-L1, IDO, and T(regs) in the melanoma tumor microenvironment is driven by $\mathrm{CD} 8(+) \mathrm{T}$ cells. Sci Transl Med 2013;5(200):200ra116

46. Liang SC, Latchman YE, Buhlmann JE, Tomczak MF, Horwitz $\mathrm{BH}$, Freeman GJ, et al. Regulation of PD-1, PD-L1, and PD-L2 expression during normal and autoimmune responses. Eur $\mathbf{J}$ Immunol 2003;33(10):2706-2716

47. Collins M, Ling V, Carreno BM. The B7 family of immuneregulatory ligands. Genome Biol 2005;6(6):223

48. Keir ME, Butte MJ, Freeman GJ, Sharpe AH. PD-1 and its ligands in tolerance and immunity. Annu Rev Immunol 2008;26(1):677-704

49. Azuma T, Yao S, Zhu G, Flies AS, Flies SJ, Chen L. B7-H1 is a ubiquitous antiapoptotic receptor on cancer cells. Blood 2008;111(7):3635-3643

50. Eissner G, Kolch W, Scheurich P. Ligands working as receptors: reverse signaling by members of the TNF superfamily enhance the plasticity of the immune system. Cytokine Growth Factor Rev 2004;15(5):353-366

51. Munn DH, Sharma MD, Mellor AL. Ligation of B7-1/B7-2 by human $\mathrm{CD} 4+\mathrm{T}$ cells triggers indoleamine 2,3-dioxygenase activity in dendritic cells. J Immunol 2004;172(7):4100-4110

52. Butte MJ, Keir ME, Phamduy TB, Freeman GJ, Sharpe AH. PDL1 interacts specifically with B7-1 to inhibit T cell proliferation. Immunity 2007;27(1):111-122

53. Park J-J, Omiya R, Matsumura Y, Sakoda Y, Kuramasu A, Augustine MM, et al. B7-H1/CD80 interaction is required for the induction and maintenance of peripheral T-cell tolerance. Blood 2010;116(8):1291-1298

54. Pardoll DM. The blockade of immune checkpoints in cancer immunotherapy. Nat Rev Cancer 2012;12(4):252-264

55. Said EA, Dupuy FP, Trautmann L, Zhang Y, Shi Y, El-Far M, et al. Programmed death-1-induced interleukin-10 production by monocytes impairs CD4 $+\mathrm{T}$ cell activation during HIV infection. Nat Med 2010;16(4):452-459

56. Monney L, Sabatos CA, Gaglia JL, Ryu A, Waldner H, Chernova $\mathrm{T}$, et al. Th1-specific cell surface protein Tim-3 regulates macrophage activation and severity of an autoimmune disease. Nature 2002;415(6871):536-541

57. Zhu C, Anderson AC, Schubart A, Xiong H, Imitola J, Khoury SJ, et al. The Tim-3 ligand galectin- 9 negatively regulates $\mathrm{T}$ helper type 1 immunity. Nat Immunol 2005;6(12):1245-1252

58. Hastings WD, Anderson DE, Kassam N, Koguchi K, Greenfield EA, Kent SC, et al. TIM-3 is expressed on activated human CD4 + T cells and regulates Th1 and Th17 cytokines. Eur J Immunol 2009;39(9):2492-2501

59. Dong J, Yang X-F, Wang L-X, Wei X, Wang A-H, Hao C-Q, et al. Modulation of Tim-3 expression by antigen-dependent and -independent factors on $\mathrm{T}$ cells from patients with chronic hepatitis B virus infection. Front Cell Infect Microbiol 2017;7:98

60. Mujib S, Jones RB, Lo C, Aidarus N, Clayton K, Sakhdari A, et al. Antigen-independent induction of Tim-3 expression on human $\mathrm{T}$ cells by the common $\gamma$-chain cytokines IL- 2 , IL-7, IL15 , and IL-21 is associated with proliferation and is dependent on the phosphoinositide 3-kinase pathway. J Immunol Baltim Md 1950 2012;188(8):3745-3756

61. Asakura H, Kashio Y, Nakamura K, Seki M, Dai S, Shirato Y, et al. Selective eosinophil adhesion to fibroblast via IFNgamma-induced galectin-9. J Immunol Baltim Md 1950 2002;169(10):5912-5918

62. Jones RB, Ndhlovu LC, Barbour JD, Sheth PM, Jha AR, Long BR, et al. Tim-3 expression defines a novel population of dysfunctional $\mathrm{T}$ cells with highly elevated frequencies in progressive HIV-1 infection. J Exp Med 2008;205(12):2763-2779
63. Golden-Mason L, Palmer BE, Kassam N, Townshend-Bulson L, Livingston $\mathrm{S}$, McMahon $\mathrm{BJ}$, et al. Negative immune regulator Tim-3 is overexpressed on T cells in hepatitis $C$ virus infection and its blockade rescues dysfunctional CD4 + and CD8 $+\mathrm{T}$ cells. J Virol 2009;83(18):9122-9130

64. Liu Y, Gao L-F, Liang X-H, Ma C-H. Role of Tim-3 in hepatitis $\mathrm{B}$ virus infection: an overview. World $\mathrm{J}$ Gastroenterol 2016;22(7):2294-2303

65. Fourcade J, Sun Z, Benallaoua M, Guillaume P, Luescher IF, Sander C, et al. Upregulation of Tim-3 and PD-1 expression is associated with tumor antigen-specific CD8 $+\mathrm{T}$ cell dysfunction in melanoma patients. J Exp Med 2010;207(10):2175-2186

66. Sakuishi K, Apetoh L, Sullivan JM, Blazar BR, Kuchroo VK, Anderson AC. Targeting Tim-3 and PD-1 pathways to reverse T cell exhaustion and restore anti-tumor immunity. J Exp Med 2010;207(10):2187-2194

67. Sakuishi K, Jayaraman P, Behar SM, Anderson AC, Kuchroo VK. Emerging Tim-3 functions in anti-microbial and tumor immunity. Trends Immunol 2011;32(8):345-349

68. Jin H-T, Anderson AC, Tan WG, West EE, Ha S-J, Araki K, et al. Cooperation of Tim-3 and PD-1 in CD8 T-cell exhaustion during chronic viral infection. Proc Natl Acad Sci USA 2010;107(33):14733-14738

69. Baitsch L, Legat A, Barba L, Fuertes Marraco SA, Rivals J-P, Baumgaertner $\mathrm{P}$, et al. Extended co-expression of inhibitory receptors by human $\mathrm{CD} 8 \mathrm{~T}$-cells depending on differentiation, antigen-specificity and anatomical localization. PLoS One 2012;7(2):e30852

70. Ngiow SF, von Scheidt B, Akiba H, Yagita H, Teng MWL, Smyth MJ. Anti-TIM3 antibody promotes T cell IFN- $\gamma$-mediated antitumor immunity and suppresses established tumors. Cancer Res 2011;71(10):3540-3551

71. Sada-Ovalle I, Chávez-Galán L, Torre-Bouscoulet L, NavaGamiño L, Barrera L, Jayaraman P, et al. The Tim3-galectin 9 pathway induces antibacterial activity in human macrophages infected with Mycobacterium tuberculosis. J Immunol Baltim Md 1950 2012;189(12):5896-5902

72. Qiu Y, Chen J, Liao H, Zhang Y, Wang H, Li S, et al. Tim-3expressing $\mathrm{CD} 4+$ and $\mathrm{CD} 8+\mathrm{T}$ cells in human tuberculosis (TB) exhibit polarized effector memory phenotypes and stronger anti-TB effector functions. PLoS Pathog 2012;8(11):e1002984

73. Jayaraman P, Sada-Ovalle I, Beladi S, Anderson AC, Dardalhon V, Hotta C, et al. Tim3 binding to galectin-9 stimulates antimicrobial immunity. J Exp Med 2010;207(11):2343-2354

74. Wang X, Cao Z, Jiang J, Li Y, Dong M, Ostrowski M, et al. Elevated expression of Tim-3 on CD8 T cells correlates with disease severity of pulmonary tuberculosis. J Infect 2011;62(4):292-300

75. Collins AV, Brodie DW, Gilbert RJC, Iaboni A, Manso-Sancho $\mathrm{R}$, Walse $\mathrm{B}$, et al. The interaction properties of costimulatory molecules revisited. Immunity 2002;17(2):201-210

76. Marengère LE, Waterhouse P, Duncan GS, Mittrücker HW, Feng GS, Mak TW. Regulation of T cell receptor signaling by tyrosine phosphatase SYP association with CTLA-4. Science 1996;272(5265):1170-1173

77. Chuang E, Fisher TS, Morgan RW, Robbins MD, Duerr JM, Vander Heiden MG, et al. The CD28 and CTLA- 4 receptors associate with the serine/threonine phosphatase PP2A. Immunity 2000;13(3):313-322

78. Qureshi OS, Zheng Y, Nakamura K, Attridge K, Manzotti C, Schmidt EM, et al. Trans-endocytosis of CD80 and CD86: a molecular basis for the cell extrinsic function of CTLA-4. Science 2011;332(6029):600-603

79. Yao S, Zhu Y, Zhu G, Augustine M, Zheng L, Goode DJ, et al. B7-h2 is a costimulatory ligand for CD28 in human. Immunity 2011;34(5):729-740 
80. Triebel F, Jitsukawa S, Baixeras E, Roman-Roman S, Genevee C, Viegas-Pequignot E, et al. LAG-3, a novel lymphocyte activation gene closely related to CD4. J Exp Med 1990;171(5):1393-1405

81. Huang C-T, Workman CJ, Flies D, Pan X, Marson AL, Zhou G, et al. Role of LAG-3 in regulatory $\mathrm{T}$ cells. Immunity 2004;21(4):503-513

82. Blackburn SD, Shin H, Haining WN, Zou T, Workman CJ, Polley A, et al. Coregulation of $\mathrm{CD} 8+\mathrm{T}$ cell exhaustion by multiple inhibitory receptors during chronic viral infection. Nat Immunol 2009;10(1):29-37

83. Grosso JF, Goldberg MV, Getnet D, Bruno TC, Yen H-R, Pyle $\mathrm{KJ}$, et al. Functionally distinct LAG-3 and PD-1 subsets on activated and chronically stimulated CD8 T cells. J Immunol Baltim Md 1950 2009;182(11):6659-6669

84. Grosso JF, Kelleher CC, Harris TJ, Maris CH, Hipkiss EL, De Marzo A, et al. LAG-3 regulates CD8 $+\mathrm{T}$ cell accumulation and effector function in murine self- and tumor-tolerance systems. J Clin Investig 2007;117(11):3383-3392

85. Woo S-R, Turnis ME, Goldberg MV, Bankoti J, Selby M, Nirschl CJ, et al. Immune inhibitory molecules LAG-3 and PD-1 synergistically regulate $\mathrm{T}$-cell function to promote tumoral immune escape. Cancer Res 2012;72(4):917-927

86. Barber DL, Wherry EJ, Masopust D, Zhu B, Allison JP, Sharpe $\mathrm{AH}$, et al. Restoring function in exhausted CD8 $\mathrm{T}$ cells during chronic viral infection. Nature 2006;439(7077):682-687

87. Trautmann L, Janbazian L, Chomont N, Said EA, Gimmig S, Bessette B, et al. Upregulation of PD-1 expression on HIVspecific CD8 $+\mathrm{T}$ cells leads to reversible immune dysfunction. Nat Med 2006;12(10):1198-1202

88. Day CL, Kaufmann DE, Kiepiela P, Brown JA, Moodley ES, Reddy $\mathrm{S}$, et al. PD-1 expression on HIV-specific T cells is associated with T-cell exhaustion and disease progression. Nature 2006;443(7109):350-354

89. Urbani S, Amadei B, Tola D, Massari M, Schivazappa S, Missale $\mathrm{G}$, et al. PD-1 expression in acute hepatitis $\mathrm{C}$ virus (HCV) infection is associated with $\mathrm{HCV}$-specific CD8 exhaustion. J Virol 2006;80(22):11398-11403

90. Boni C, Fisicaro P, Valdatta C, Amadei B, Di Vincenzo P, Giuberti T, et al. Characterization of hepatitis B virus (HBV)specific T-cell dysfunction in chronic HBV infection. J Virol 2007;81(8):4215-4225

91. Penna A, Pilli M, Zerbini A, Orlandini A, Mezzadri S, Sacchelli $\mathrm{L}$, et al. Dysfunction and functional restoration of $\mathrm{HCV}$-specific CD8 responses in chronic hepatitis $\mathrm{C}$ virus infection. Hepatology 2007;45(3):588-601

92. Golden-Mason L, Palmer B, Klarquist J, Mengshol JA, Castelblanco N, Rosen HR. Upregulation of PD-1 expression on circulating and intrahepatic hepatitis $\mathrm{C}$ virus-specific CD8 $+\mathrm{T}$ cells associated with reversible immune dysfunction. J Virol 2007;81(17):9249-9258

93. Evans A, Riva A, Cooksley H, Phillips S, Puranik S, Nathwani A, et al. Programmed death 1 expression during antiviral treatment of chronic hepatitis B: Impact of hepatitis B e-antigen seroconversion. Hepatol Baltim Md 2008;48(3):759-769

94. Boettler T, Panther E, Bengsch B, Nazarova N, Spangenberg $\mathrm{HC}$, Blum HE, et al. Expression of the interleukin-7 receptor alpha chain (CD127) on virus-specific CD8 + T cells identifies functionally and phenotypically defined memory $\mathrm{T}$ cells during acute resolving hepatitis $B$ virus infection. $J$ Virol 2006;80(7):3532-3540

95. Zou W, Chen L. Inhibitory B7-family molecules in the tumour microenvironment. Nat Rev Immunol 2008;8(6):467-477

96. Dong H, Strome SE, Salomao DR, Tamura H, Hirano F, Flies DB, et al. Tumor-associated B7-H1 promotes T-cell apoptosis: a potential mechanism of immune evasion. Nat Med 2002;8(8):793-800

97. Iwai Y, Ishida M, Tanaka Y, Okazaki T, Honjo T, Minato N. Involvement of PD-L1 on tumor cells in the escape from host immune system and tumor immunotherapy by PD-L1 blockade. Proc Natl Acad Sci USA 2002;99(19):12293-12297

98. Konishi J, Yamazaki K, Azuma M, Kinoshita I, Dosaka-Akita H, Nishimura M. B7-H1 expression on non-small cell lung cancer cells and its relationship with tumor-infiltrating lymphocytes and their PD- 1 expression. Clin Cancer Res Off J Am Assoc Cancer Res 2004;10(15):5094-5100

99. Hamanishi J, Mandai M, Iwasaki M, Okazaki T, Tanaka Y, Yamaguchi $\mathrm{K}$, et al. Programmed cell death 1 ligand 1 and tumor-infiltrating CD8 $+\mathrm{T}$ lymphocytes are prognostic factors of human ovarian cancer. Proc Natl Acad Sci USA 2007;104(9):3360-3365

100. Hino R, Kabashima K, Kato Y, Yagi H, Nakamura M, Honjo T, et al. Tumor cell expression of programmed cell death-1 ligand 1 is a prognostic factor for malignant melanoma. Cancer 2010;116(7):1757-1766

101. Parsa AT, Waldron JS, Panner A, Crane CA, Parney IF, Barry JJ, et al. Loss of tumor suppressor PTEN function increases B7$\mathrm{H} 1$ expression and immunoresistance in glioma. Nat Med 2007;13(1):84-88

102. Marzec M, Zhang Q, Goradia A, Raghunath PN, Liu X, Paessler $M$, et al. Oncogenic kinase NPM/ALK induces through STAT3 expression of immunosuppressive protein CD274 (PD-L1, B7H1). Proc Natl Acad Sci USA 2008;105(52):20852-20857

103. Kim J, Myers AC, Chen L, Pardoll DM, Truong-Tran Q-A, Lane $\mathrm{AP}$, et al. Constitutive and inducible expression of b7 family of ligands by human airway epithelial cells. Am J Respir Cell Mol Biol 2005;33(3):280-289

104. Wilke CM, Wei S, Wang L, Kryczek I, Kao J, Zou W. Dual biological effects of the cytokines interleukin-10 and interferon$\gamma$. Cancer Immunol Immunother CII 2011;60(11):1529-1541

105. Kaunitz GJ, Cottrell TR, Lilo M, Muthappan V, Esandrio J, Berry S, et al. Melanoma subtypes demonstrate distinct PD-L1 expression profiles. Lab Investig $\mathrm{J}$ Tech Methods Pathol 2017;97(9): 1063-1071

106. Taube JM, Young GD, McMiller TL, Chen S, Salas JT, Pritchard TS, et al. Differential Expression of immune-regulatory genes associated with PD-L1 display in melanoma: implications for PD-1 pathway blockade. Clin Cancer Res Off J Am Assoc Cancer Res 2015;21(17):3969-3976

107. Taube JM, Anders RA, Young GD, Xu H, Sharma R, McMiller $\mathrm{TL}$, et al. Colocalization of inflammatory response with B7-h1 expression in human melanocytic lesions supports an adaptive resistance mechanism of immune escape. Sci Transl Med 2012;4(127):127ra37

108. Memarnejadian A, Meilleur CE, Shaler CR, Khazaie K, Bennink JR, Schell TD, et al. PD-1 blockade promotes epitope spreading in anticancer $\mathrm{CD} 8+\mathrm{T}$ cell responses by preventing fratricidal death of subdominant clones to relieve immunodomination. J Immunol Baltim Md 1950 2017;199(9):3348-3359

109. Sangro B, Gomez-Martin C, de la Mata M, Iñarrairaegui M, Garralda E, Barrera P, et al. A clinical trial of CTLA-4 blockade with tremelimumab in patients with hepatocellular carcinoma and chronic hepatitis C. J Hepatol 2013;59(1):81-88

110. El-Khoueiry AB, Sangro B, Yau T, Crocenzi TS, Kudo M, Hsu $\mathrm{C}$, et al. Nivolumab in patients with advanced hepatocellular carcinoma (CheckMate 040): an open-label, non-comparative, phase $1 / 2$ dose escalation and expansion trial. Lancet 2017;389(10088):2492-2502

111. Topalian SL, Hodi FS, Brahmer JR, Gettinger SN, Smith DC, McDermott DF, et al. Safety, activity, and immune correlates of 
anti-PD-1 antibody in cancer. $\mathrm{N}$ Engl $\mathrm{J}$ Med 2012;366(26):2443-2454

112. Brahmer JR, Tykodi SS, Chow LQM, Hwu W-J, Topalian SL, Hwu P, et al. Safety and activity of anti-PD-L1 antibody in patients with advanced cancer. $N$ Engl $J$ Med 2012;366(26):2455-2465

113. Phan GQ, Yang JC, Sherry RM, Hwu P, Topalian SL, Schwartzentruber DJ, et al. Cancer regression and autoimmunity induced by cytotoxic $\mathrm{T}$ lymphocyte-associated antigen 4 blockade in patients with metastatic melanoma. Proc Natl Acad Sci USA 2003;100(14):8372-8377

114. Downey SG, Klapper JA, Smith FO, Yang JC, Sherry RM, Royal RE, et al. Prognostic factors related to clinical response in patients with metastatic melanoma treated by CTL-associated antigen-4 blockade. Clin Cancer Res Off J Am Assoc Cancer Res 2007;13(22 Pt 1):6681-6688

115. Hodi FS, Mihm MC, Soiffer RJ, Haluska FG, Butler M, Seiden $\mathrm{MV}$, et al. Biologic activity of cytotoxic T lymphocyte-associated antigen 4 antibody blockade in previously vaccinated metastatic melanoma and ovarian carcinoma patients. Proc Natl Acad Sci USA 2003;100(8):4712-4717

116. Hodi FS, O'Day SJ, McDermott DF, Weber RW, Sosman JA, Haanen JB, et al. Improved survival with ipilimumab in patients with metastatic melanoma. N Engl J Med 2010;363(8):711-723

117. Hamid O, Robert C, Daud A, Hodi FS, Hwu W-J, Kefford R, et al. Safety and tumor responses with lambrolizumab (anti-PD1) in melanoma. N Engl J Med 2013;369(2):134-144

118. Robert C, Ribas A, Wolchok JD, Hodi FS, Hamid O, Kefford R, et al. Anti-programmed-death-receptor-1 treatment with pembrolizumab in ipilimumab-refractory advanced melanoma: a randomised dose-comparison cohort of a phase 1 trial. Lancet Lond Engl 2014;384(9948):1109-1117

119. Llovet JM, Ricci S, Mazzaferro V, Hilgard P, Gane E, Blanc $\mathrm{J}-\mathrm{F}$, et al. Sorafenib in advanced hepatocellular carcinoma. N Engl J Med 2008;359(4):378-390

120. Kaplon H, Reichert JM. Antibodies to watch in 2018. mAbs 2018;10(2):183-203

121. Vanpouille-Box C, Lhuillier C, Bezu L, Aranda F, Yamazaki T, Kepp O, et al. Trial watch: Immune checkpoint blockers for cancer therapy. OncoImmunology 2017;6(11):e1373237

122. Home-ClinicalTrials.gov. https://clinicaltrials.gov/ct2/home. Accessed 6 Apr 2018

123. NCI Drug Dictionary. National Cancer Institute. https://www. cancer.gov/publications/dictionaries/cancer-drug. Accessed 6 Apr 2018

124. NCI Thesaurus. https://ncit.nci.nih.gov/ncitbrowser/pages/ home.jsf. Accessed 6 Apr 2018

125. Shubin NJ, Monaghan SF, Ayala A. Anti-inflammatory mechanisms of sepsis. Contrib Microbiol 2011;17:108-124

126. Adib-Conquy M, Cavaillon J-M. Compensatory anti-inflammatory response syndrome. Thromb Haemost 2009;101(1):36-47

127. Ward NS, Casserly B, Ayala A. The compensatory anti-inflammatory response syndrome (CARS) in critically ill patients. Clin Chest Med 2008;29(4):617-625 (viii)

128. Gentile LF, Cuenca AG, Efron PA, Ang D, Bihorac A, McKinley BA, et al. Persistent inflammation and immunosuppression: a common syndrome and new horizon for surgical intensive care. J Trauma Acute Care Surg 2012;72(6):1491-1501

129. Binkowska AM, Michalak G, Słotwiński R. Current views on the mechanisms of immune responses to trauma and infection. Cent-Eur J Immunol 2015;40(2):206-216

130. Tang BM, Huang SJ, McLean AS. Genome-wide transcription profiling of human sepsis: a systematic review. Crit Care Lond Engl 2010;14(6):R237
131. Boomer JS, Green JM, Hotchkiss RS. The changing immune system in sepsis: is individualized immuno-modulatory therapy the answer? Virulence 2014;5(1):45-56

132. Osuchowski MF, Welch K, Siddiqui J, Remick DG. Circulating cytokine/inhibitor profiles reshape the understanding of the SIRS/CARS continuum in sepsis and predict mortality. J Immunol 2006;177(3):1967-1974

133. Oberholzer A, Oberholzer C, Moldawer LL. Sepsis syndromes: understanding the role of innate and acquired immunity. Shock Augusta Ga 2001;16(2):83-96

134. Lu J, Goh SJ, Tng PYL, Deng YY, Ling E-A, Moochhala S. Systemic inflammatory response following acute traumatic brain injury. Front Biosci Landmark Ed 2009;14:3795-3813

135. Russell JA. Management of sepsis. N Engl J Med 2006;355(16):1699-1713

136. Hotchkiss RS, Karl IE. The pathophysiology and treatment of sepsis. N Engl J Med 2003;348(2):138-150

137. Angus DC. The search for effective therapy for sepsis: back to the drawing board? JAMA 2011;306(23):2614-2615

138. Cohen J, Opal S, Calandra T. Sepsis studies need new direction. Lancet Infect Dis 2012;12(7):503-505

139. Brahmamdam P, Inoue S, Unsinger J, Chang KC, McDunn JE, Hotchkiss RS. Delayed administration of anti-PD-1 antibody reverses immune dysfunction and improves survival during sepsis. J Leukoc Biol 2010;88(2):233-240

140. Goyert SM, Silver J. Editorial: PD-1, a new target for sepsis treatment: better late than never. $J$ Leukoc Biol 2010;88(2):225-226

141. Shao R, Fang Y, Yu H, Zhao L, Jiang Z, Li C-S. Monocyte programmed death ligand-1 expression after 3-4 days of sepsis is associated with risk stratification and mortality in septic patients: a prospective cohort study. Crit Care 2016;20(1):124

142. Monneret G, Gossez M, Venet F. Sepsis in PD-1 light. Crit Care 2016;20:186

143. Gao D-N, Yang Z-X, Qi Q-H. Roles of PD-1, Tim-3 and CTLA4 in immunoregulation in regulatory $\mathrm{T}$ cells among patients with sepsis. Int J Clin Exp Med 2015;8(10):18998-19005

144. Boomer JS, To K, Chang KC, Takasu O, Osborne DF, Walton $\mathrm{AH}$, et al. Immunosuppression in patients who die of sepsis and multiple organ failure. JAMA 2011;306(23):2594-2605

145. Boomer JS, Shuherk-Shaffer J, Hotchkiss RS, Green JM. A prospective analysis of lymphocyte phenotype and function over the course of acute sepsis. Crit Care Lond Engl 2012;16(3):R112

146. Patera AC, Drewry AM, Chang K, Beiter ER, Osborne D, Hotchkiss RS. Frontline Science: Defects in immune function in patients with sepsis are associated with PD-1 or PD-L1 expression and can be restored by antibodies targeting PD- 1 or PD-L1. J Leukoc Biol 2016;100(6):1239-1254

147. Hotchkiss RS, Monneret G, Payen D. Sepsis-induced immunosuppression: from cellular dysfunctions to immunotherapy. Nat Rev Immunol 2013;13(12):862-874

148. Zhu W, Bao R, Fan X, Tao T, Zhu J, Wang J, et al. PD-L1 blockade attenuated sepsis-induced liver injury in a mouse cecal ligation and puncture model. Mediators Inflamm 2013;2013:361501

149. Lumsden AB, Henderson JM, Kutner MH. Endotoxin levels measured by a chromogenic assay in portal, hepatic and peripheral venous blood in patients with cirrhosis. Hepatol Baltim Md 1988;8(2):232-236

150. Chen J, Wang X-M, Wu X-J, Wang Y, Zhao H, Shen B, et al. Intrahepatic levels of PD-1/PD-L correlate with liver inflammation in chronic hepatitis B. Inflamm Res Off J Eur Histamine Res Soc Al 2011;60(1):47-53

151. Zhang Y, Zhou Y, Lou J, Li J, Bo L, Zhu K, et al. PD-L1 blockade improves survival in experimental sepsis by inhibiting 
lymphocyte apoptosis and reversing monocyte dysfunction. Crit Care Lond Engl 2010;14(6):R220

152. Yoest JM. Clinical features, predictive correlates, and pathophysiology of immune-related adverse events in immune checkpoint inhibitor treatments in cancer: a short review. ImmunoTargets Ther 2017;6:73-82

153. Postow MA, Sidlow R, Hellmann MD. Immune-related adverse events associated with immune checkpoint blockade. N Engl J Med 2018;378(2):158-168

154. O'Donnell JS, Long GV, Scolyer RA, Teng MWL, Smyth MJ. Resistance to PD1/PDL1 checkpoint inhibition. Cancer Treat Rev 2017;52:71-81

155. Benci JL, Xu B, Qiu Y, Wu TJ, Dada H, Twyman-Saint Victor $\mathrm{C}$, et al. Tumor interferon signaling regulates a multigenic resistance program to immune checkpoint blockade. Cell 2016;167(6):1540-1554.e12

156. Sade-Feldman M, Jiao YJ, Chen JH, Rooney MS, Barzily-Rokni M, Eliane J-P, et al. Resistance to checkpoint blockade therapy through inactivation of antigen presentation. Nat Commun 2017;8(1):1136

157. Gandini S, Massi D, Mandalà M. PD-L1 expression in cancer patients receiving anti PD-1/PD-L1 antibodies: a systematic review and meta-analysis. Crit Rev Oncol Hematol 2016;100:88-98

158. Zhang T, Fan R, Shi N, Ma W. The efficacy and safety of antiPD-1/PD-L1 antibodies for treatment of advanced or refractory cancers: a meta-analysis. J Clin Oncol 2017;35(15_suppl):e23075-e23075

159. Maleki Vareki S, Garrigós C, Duran I. Biomarkers of response to PD-1/PD-L1 inhibition. Crit Rev Oncol Hematol 2017;116:116-124

160. Garg AD, Vandenberk L, Van Woensel M, Belmans J, Schaaf M, Boon L, et al. Preclinical efficacy of immune-checkpoint monotherapy does not recapitulate corresponding biomarkersbased clinical predictions in glioblastoma. Oncoimmunology 2017;6(4):e1295903

161. Zhu X, Lang J. Soluble PD-1 and PD-L1: predictive and prognostic significance in cancer. Oncotarget 2017;8(57):97671-97682
162. Li YM, Shi YY, Li Y, Yan L, Tang JT, Bai YJ, et al. Soluble Tim-3 and Gal-9 are associated with renal allograft dysfunction in kidney transplant recipients: a cross-sectional study. Int Immunopharmacol 2018;55:330-335

163. Chen D, Peng W, Jiang H, Yang H, Wu J, Wang H, et al. Noninvasive detection of acute renal allograft rejection by measurement of soluble Tim-3 in urine. Mol Med Rep 2017;16(1):915-921

164. Dahal LN, Basu N, Youssef H, Khanolkar RC, Barker RN, Erwig LP, et al. Immunoregulatory soluble CTLA-4 modifies effector T-cell responses in systemic lupus erythematosus. Arthritis Res Ther 2016;18:180

165. Ren F, Li J, Jiang X, Xiao K, Zhang D, Zhao Z, et al. Plasma soluble Tim-3 emerges as an inhibitor in sepsis: sepsis contrary to membrane Tim-3 on monocytes. Tissue Antigens 2015;86(5):325-332

166. Simone R, Pesce G, Antola P, Rumbullaku M, Bagnasco M, Bizzaro N, et al. The soluble form of CTLA-4 from serum of patients with autoimmune diseases regulates T-cell responses. BioMed Res Int 2014;2014:215763

167. Casati C, Camisaschi C, Rini F, Arienti F, Rivoltini L, Triebel F, et al. Soluble human LAG-3 molecule amplifies the in vitro generation of type 1 tumor-specific immunity. Cancer Res 2006;66(8):4450-4460

168. Horn LA, Long TM, Atkinson R, Clements V, Ostrand-Rosenberg S. Soluble CD80 protein delays tumor growth and promotes tumor-infiltrating lymphocytes. Cancer Immunol Res 2018;6(1):59-68

169. Haile ST, Horn LA, Ostrand-Rosenberg S. A soluble form of CD80 enhances antitumor immunity by neutralizing programmed death ligand-1 and simultaneously providing costimulation. Cancer Immunol Res 2014;2(7):610-615

170. Riva A, Adams H, Patel V, Azarian S, Wright G, Tarff S, et al. The TIM3-Gal9 immune checkpoint axis is inter-linked with severity of Alcoholic Liver Disease. J Hepatol 2018;68:S810 S811 